\title{
The most important things I learnt in practice
}

Heramaahina Eketone, (Ngāti Maniapoto, Waikato)

Growing up with two social worker parents, I was always going to end up working with people. Right from when I was a tamaiti, my father wouldn't say "What do you want to be when you grow up?" it was "How are you going to help our people, what are you going to do?"- -no pressure there! I ended up studying social work and having a father as a lecturer was difficult at times, because right from the start he said, "Because you're my daughter you won't get any help from me, if you want to ask something, ask someone else." However, Shayne Walker was also there and he really looked after me. There were tuakana in the department like Awhina Hollis, Suzi Wereta, Justine Camp and Kerri Cleaver, who were a few years ahead of me and really looked after me as well. So I was the lecturer's daughter, the brat, I guess and I got my revenge on Dad at the end of year when you do your reviews of your lecturers: "Has your lecturer been helpful?" — "Not at all!"-I thought I was being a bit hilarious. My mother was furious because I didn't realise that poor reviews could potentially affect things like promotions. What an actual brat.

As well as graduating in Social Work and Community Work, I also I did a Bachelor's Degree in Māori Studies, and a Diploma for Graduates in Whakairo/carving. There was a Whakairo course at university, which I did for three years at the same time as social work. After I graduated with my Social and Community Work qualification, I was employed by the Mãori mental health team, Te Oranga Tonu Tanga, based at Wakaari hospital in Dunedin as a Kaioranga Hauora Māori, a Mental Health Clinician. The things that I learnt through study, life and at Te Oranga Tonu Tanga were the things that have got me to this point right now and I don't think I would be here, especially, without those things.

Some of you will know one of the taniwha of Dunedin, Reitu Cassidy, and by taniwha I mean a rangatira (nah, taniwha). She is one of my biggest mentors, my tuakana, because she is a real stickler for tikanga. When you think about keeping or having kaupapa Māori within organisations, you look at her and she's: "Do it this way, you do it this way every single time," and she's really staunch. We need those mana wahine around us, to lift us up as wāhine, to feed that kōrero, so she is definitely a stickler for the rules, "This is how you do it," particularly with tikanga Māori.

There were a few other tuakana/taniwha at Te Oranga Tonu Tanga, Raewyn Nafatali, Sarah Martin, and Isobel Wheelan. Isobel was so knowledgeable in Māori models of practice especially in Māori mental health. She was taught by the best, Rose Pere, Mason Durie, and Paraire Huata to name a few. But when she was at the pinnacle of matauranga Māori, sadly she passed away. The things that I learnt under her were pure magic, because I was lucky enough to be her shadow. So those four wāhine, in practice, they really looked after me. I've always needed looking after. Awhina Hollis-English talks about having those quality people around you-you find them and you do not let them go. We still catch up years after I left Māori Mental Health, I still keep in close contact with three of them, and the fourth one's looking over us.

I was working with rangatahi at Te Oranga Tonu Tanga but got to a space where
AOTEAROA NEW ZEALAND SOCIAL WORK 32(3), 85-87.

CORRESPONDENCE TO: Heramaahina Eketone Heramaahina.Eketone@ twoa.ac.nz 
I couldn't do it anymore after the passing of my cousin. I found I needed to take some time away from that intense mahi and focus on other things.

I am a toi person, I have always been involved in various kinds of Māori art and so now I teach Kāwai Raupapa level 4, an 'Introduction to Māori Art,' at Te Wananga o Aotearoa. I am also an apprentice Tā Moko artist under Stu McDonald of Moana moko. I've been training, practising on my kiri tuhi, my uncle for the past $2 \frac{1}{2} 2$ years and in $2019 \mathrm{I}$ branched out to moko people who are not my whānau. One of the approaches to moko that I have been encouraged by my kaiako to grow in, is its use to bring about emotional, mental and spiritual healing. It is interestingly the way that my training as a social worker, my interest in Māori art and my experience as a mental health worker have been brought together to work with people, especially regarding tikanga and what this means for my own self-care as a practitioner.

As Māori workers, we often forget about self-care because the focus is so much on our clients and their whānau. So it is important that we consider self-care and the way we look after ourselves, especially when we deal with circumstances that are heavy and weigh on our minds. When this happens, I have found that we need to find a way to whakanoa ourselves, to emotionally, spiritually cleanse, and restore ourselves.

We all know that there are things that we do to look after ourselves, things that settle us emotionally, physically and spiritually. What I'm really learning with moko is that you don't want to give your own hara, your own stuff, to anybody. The client is in a vulnerable position and has to trust you and your processes. With moko, it really comes to the forefront of, not just self-care-because you should be doing self-care all the timebut to whakanoa. I didn't do that when I was working in mental health. I should have been doing that process after every client, or after every day, I should have been doing whakanoa and that's to remove any of that tapu, any of that hara, mamae that might be lingering around and there are a number of things we can do to whakanoa ourselves.

There are a few of the things that provide that whakanoa-karakia is the first one. We should all have karakia whether they are to Te Atua ki runga, Te Ao Hurihuri or Te Ao Katoa, those kupu, those words that clear away those things that can be negative. It doesn't matter if you don't even feel that there's anything there, just do it anyway because it actually clears that way for you as we are not always aware when things are happening in these different realms.

Water, is another one. You know we go to urupa or we go to tangi and when we leave, we sprinkle ourselves with water and often that is the only time that we do it. We should be doing it anywhere and anytime. So every once in a while, not every time, but after doing moko, I'll just sprinkle some water and cleanse myself out emotionally and spiritually through this physical action.

Kai is another one because kai is also noa. For instance, in Ngāpuhi, some people grab the bread and do the same thing as we do in Tainui with water, it's just as noa. Debriefing with kōrero. Having a tangi, shedding tears, where tears are salt water. Sea water, salt water is a rongoā, it's a medicine, and it's in us so if we have a tangi our hara gets attached to that and we can get rid of it through having a cry.

Having a shower that's like extra. So you've done your sprinkle and you're still feeling a bit yuck, or a bit tense, you've had a kai. It's still not working, you have a cry, and so go for shower or a swim. Get bucket-loads of water.

The last thing, and this will be controversial to some, is that sometimes the most noa thing for me, is a good cold beer. The reason why I know that this works and is true is that I did a little traveling a few years ago and ended up in Germany. I was with a group of Mãori who went to a concentration camp. We went in and came out and we did it all ... we did the karakia, the wai, the kai ... but we just 
couldn't get that mamae off us. The mamae was too much but as soon as we cracked open a beer-waipiro or rotten water is so noa, I felt normal again. I'm not talking about hitting the piss. I'm talking about actual whakanoa-using it to get rid of that tapu and that mamae. No more than one is needed. One is to do the job, two or more are for fun.

Sometimes these are the steps for me, other times I just need a karakia, that's all I need to rid myself of something. What I learned in social work was being able to listen to kōrero from clients and not take it on or let it affect my inner self. It was probably the most powerful thing that I learnt there, that you don't actually have to carry other people's mamae. Another thing, and this was a hard lesson that I learnt, is you cannot work one way and live another. I'm talking about, not just the extremes, but the little stuff. From encouraging people to letting things go when you can't or won't yourself, for giving advice that you don't follow to making a fool of yourself out on Saturday night when you're a drug and alcohol counsellor.

If you have those things too separate, it will catch up on you. Working in mental health it caught up on me. I wasn't looking after myself. I got to a space where I realised "I'm not in a good space, I need to leave for now." And what really helped was getting into Te Ao Toi, the art world. Before I was ready to moko other people I had done about 100 hours. Ninety hours of that has been on my uncle and 10 was on whānau. That was over $2 \frac{1}{2}$ years, 100 hours-it isn't a lot. People think I've been dragging my feet and I have in a way, but the reason is because I've wanted to be clear, I want to be free and light and utterly safe for anybody who lies on that table so that when they give me their precious kōrero it's not going to touch me. It's not going to hurt them and when they get back off the moko table it's a new kōrero, it's a new space for that person. So I spent 100 hours on moko but a good 2,000 hours on myself-on sorting my shit out. I had to because I was working with youth and my kōrero was "sort your shit out"... but I didn't sort it out myself. So that kōrero-that idea of sorting it out, sorting yourself out, so that when you step in front of those people that are literally giving you their all, that they are safe because you're safe.

I had in my mind, as a Māori social worker, this idea of being professional or being seen as professional. That idea of earning it, or being in that space where, "Yeah I actually feel that I can contribute and help people." It's in our blood. We have been drawn to this profession or to this space to work with people. Whether it's in a social work capacity, or in a moko capacity, or a kaiako capacity it doesn't actually matter. What this space is teaching us is how to look after ourselves, work with other people, and know that we' ve earned it.

Just like with moko, if you're Māori you've earned it already. It's in your blood. It's not about earning or coming up with a goal, that's fine, but that's you. That's your own making. But don't let those things hold you back from doing what you're actually supposed to do.

I had one other thing: toi (art) for me is rongoā. Tā Moko especially is medicine, my approach is that it is a healing practice. One of the things I'm pretty sure can be mirrored with social work, or with working with people is that moko has an utu, it has a price. Some of those prices are telling that story, being honest, being truthful, shedding mamae, getting rid of some of that pain and, in return, getting some healing especially on that spiritual side. Shedding some blood, toto, for the ink, for the story. Shedding some tears and gaining a moko, gaining a kōrero that you can wear and have for the rest of your life. So for me, moko is a physical representation of what we already have anyway, our whakapapa, our story and our ability. Māori have a real ability to work with other people, it's a real gift. For me that's my way of giving back and working with my people. My kaiako, Stu McDonald, is teaching and showing me that moko is a rongoā and that it can actually be used to heal and I totally believe that. 